\title{
GATA3 Gene Mutation
}

National Cancer Institute

\section{Source}

National Cancer Institute. GATA3 Gene Mutation. NCI Thesaurus. Code C150628.

A change in the nucleotide sequence of the GATA3 gene. 